This is the peer-reviewed version of the article

Ejd u s , F . , \& Božović, M. (2017). Grammar, Context and Power: Securitisation of 2010 Belgrade Pride Parade. Southeast European and Black Sea Studies, 17(1), 17-34.

https://doi.org/10.1080/14683857.2016.1225370

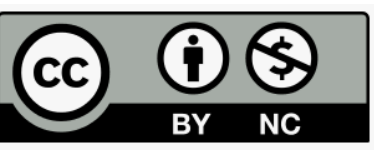

This work is licensed under the Creative Commons Attribution-NonCommercial 4.0 International license 


\section{Grammar, Context and Power: Securitisation of 2010 Belgrade Pride Parade}

In the wake of 2010 Belgrade Pride Parade, right wing extremists portrayed the event as a threat to public morals, while liberals framed homophobia as a threat to democracy. While these moves managed to polarise and mobilize the public, the government didn't heed to their calls to adopt extraordinary measures. The Parade took place on October 10 and the extremists organised unchecked violent counter-demonstrations. By drawing on Securitisation Theory, we triangulate content and discourse analysis to understand why these securitising moves had a low success. Our analysis shows that although both moves followed the grammar of security, they were only partially embedded into the wider discursive context and were not enunciated by securitising actors with strong positional power.

Key words: securitisation; Pride Parade, positional power, Serbia, LGBTIQ

\section{Intro}

In October 2000, authoritarian president Slobodan Milošević was ousted from power and Serbia started transition to liberal democracy. ${ }^{1}$ The lesbian, gay, bisexual, trans, intersex, queer (LGBTIQ) community of Serbia, which had been discriminated against under previous regimes, expected that democratization will soon bring about an improvement of their status. Only a few days following the extradition of Milošević to the war crimes tribunal in The Hague on 28 June 2001, Serbia's LGBTIQ community organised the first Pride Parade in Belgrade. Their hopes, unfortunately, turned out to be premature as approximately one thousand football hooligans and right wing extremists attacked a few dozens of parade participants. The next attempt to organise Pride Parade in 2009 was thwarted again, this time by the Serbian Police, which didn't allow the event to take place in the city centre due to security reasons. Determined to succeed next year, Serbia's LGBTIQ community scheduled the next Pride Parade for 10 October 2010. As the event approached, tensions between opponents and supporters of the parade heated up.

On the one side were conservative opponents of the event who built upon the high level of social prejudice against LGBTIQ rights and who portrayed the Pride Parade as a threat to public

\footnotetext{
${ }^{1}$ Authors would like to thank Nebojša Vladisavljević, Katrin Voltmer and two anonymous reviewers for helpful comments on earlier versions of this article. Data for the conten analysis presented in the article was gathered as part of the project Media, Conflict and Democratisation (MECODEM) funded from the European Union's Seventh Framework Programme for research, technological development and demonstration under grant agreement no 613370. For more details about the project see: www.mecodem.eu.
} 
morality and national identity. ${ }^{2}$ Consequently, they requested from the state authorities to ban the event. On the other side were liberal proponents of the Pride Parade who framed the event as an important test for Serbia's fledgling democracy. They were smaller in size but composed of a significant portion of political and cultural elite wholeheartedly endorsed by the international community and especially the EU. Liberals requested from the state authorities an imposition of harsher security measures against the opponents of the parade that used hate speech and threatened with violence. Still, neither of the camps managed to convince the government of Serbia, led by centre left Democratic Party, to adopt these measures. As a result, the Pride Parade took place while several thousand anti-Pride rioters were allowed to take to the streets, attacking the police and demolishing Belgrade city centre. How can we account for such an outcome?

The struggle to organise Pride Parades in Serbia have attracted a growing scholarly interest in the recent years. The existing research has been focusing on Europeanisation (Ejdus and Božović 2015, Bilić 2016), football hooliganism (Axboe-Nielsen 2013), democratisation (Mikuš 2011) and the role of the media (Pavasović-Trost and Kovačević 2011). In this article we draw on Securitisation Theory to provide an account of why the two above-sketched securitising moves failed to convince the government of Serbia to adopt extraordinary measures. According to the Securitisation Theory, in order to be successful, a securitising move needs to follow the grammar of security, it has to be embedded in the wider discursive context and it has to be spelled out from a position of power and authority. Methodologically, we combine content and discourse analysis. The former provides a quantitative insight into security speech acts present in the media coverage of the 2010 Pride Parade and the latter sheds light on their qualitative aspects. While fully acknowledging the epistemological tension between content and discourse analysis, we aim to demonstrate in this article the analytical added value of such methodological triangulation.

The main empirical finding of our paper is that securitisation moves conducted in the wake of the 2010 Belgrade Pride had limited success because, although following the grammar of security, they were not fully embedded in the wider discursive context and were made by actors with little positional power. Theoretically, our findings confirm the assumptions of the sociological approach to securitisation that security speech acts cannot fully succeed if they don't evoke threatening associations shared by the respective audience and if they are not enunciated

\footnotetext{
${ }^{2}$ For example, according to opinion polls conducted in March 2010, 67\% of Serbian citizens believed that homosexuality was a disease, $56 \%$ that it was dangerous for the society, while $53 \%$ held that the state should suppress homosexuality on a regular basis (Blic 2010).
} 
by actors with sufficient social capital, even if they perfectly follow the grammar of security. Methodologically, we make a case for triangulation of discourse and content analysis, so far unexplored in securitisation research. Our mixed method approach demonstrates the analytical purchase of looking not only at qualitative but also at quantitative aspects of security speech acts, without which the empirical findings would be incomplete and inconclusive. ${ }^{3}$

The structure of the article is as following. In the first section we discuss theoretical framework of this study. In the second section we first elaborate the research puzzle and then conduct content and analysis of securitising moves conducted in the wake of the 2010 Pride Parade. In the conclusion, we review our case study, reflect about its implications and propose some avenues for future research.

\section{Theoretical Framework}

Securitisation Theory was first developed by Ole Wæver. Drawing on the works of philosophers of language John Austin and John Searle, Wæver conceived security as 'speech act'. He writes:

What then is security? One can view 'security' as that which, is in language theory called a speech act: it is not interesting as a sign referring to something more real - it is the utterance in itself that is the act: by saying it something is done (like betting, giving a promise, naming a ship (1989: 5).

The 'Speech act' is carried out by the 'securitising actor' who claims that something or somebody is an 'existential threat' to a certain 'referent object' and proposes taking 'extraordinary measures'. If by means of such an argument the securitising actor manages to legitimise the measures which would not be possible to take had the discourse not taken the form of existential threats, priority and extraordinary measures - we are then witnessing a case of securitisation. In such an understanding, security is not treated as a description of an objective reality, but rather as an intersubjective process in which by framing certain issue in security terms, political rules of the game are changed and space for otherwise illegitimate extraordinary measures is expanded.

Ole Wæver continued to develop Securitisation Theory in his collaborative work within the

\footnotetext{
${ }^{3}$ Quantitative methods, often associated with positivism in social science, have rarely been used in securitisation studies. For some rare examples see: Vultee 2010, Baele and Sterck 2014
} 
Copenhagen School of Security Studies (Buzan, Wæver, and De Wilde 1998, Buzan and Waever 2003, 2009). In a seminal collaborative book, securitisation was redefined from a merely linguistic process to also include socio-political context (Buzan, Wæver, and De Wilde 1998). In it, the authors made a crucial distinction between securitising move which is an attempt to convince a particular audience that certain development is a security threat to a particular referent object and that it therefore requires extraordinary defensive measures and successful securitisation (Buzan, Wæver, and De Wilde 1998, 23).

In the years that followed the publication of the 1998 book, the above outlined Securitisation Theory has been theoretically and empirically applied, developed and challenged from a variety of perspectives (Aradau 2004, Balzacq 2005, McDonald 2008, Roe 2012, Salter 2008, Stritzel 2007, Vuori 2008, Wilkinson 2007, Williams 2003, Baele and Sterck 2014, Buzan and Wæver 2009, Wæver 2003, Vuori 2011, Pram Gad and Lund Peersen 2011, Bilgin 2011, Croft 2012, Floyd 2011, Hansen 2011). Over time, two distinct readings of securitisation have crystallized. The first approach, with strong roots in speech-act theory and post-structuralism is often referred to as philosophical (Balzacq 2010: xv). This approach, developed in Wæver's early works, focuses on the internal and linguistic rules, i.e. the grammar of security needed for successful securitisation (Wæver 1989, 1995). The second approach, which this study also takes, is sociological as it probes beyond the mere text into 'practices, context and power relations that characterize the construction of threat images' (Balzacq 2010, 15).

Doing justice to this sizeable and fast growing literature is far beyond the scope of this article. Instead of that, we will particularly draw on one particular issue that has been given a special attention in the literature: under what conditions a securitising move is more likely to succeed? According to Buzan, Wæver and De Wilde, in order to succeed, and actually produce legitimacy for exceptional measures, a securitising move has to fulfil three conditions. First, it has to follow the grammar of security. As they put it, 'the most important is to follow the security form, the grammar of security, and construct a plot that includes existential threat, point of no return, and a possible way out [...]' (Buzan et al. 1998, 33). ${ }^{4}$ Second, those who are making the attempt, i.e. securitising actors, need to have sufficient social capital meaning that they have to hold a position of power and authority. Finally, the objects that are presented as a threat have to be generally held as threatening. In other words, the speaker needs to emphasize 'aspects historically

\footnotetext{
${ }^{4}$ In addition to this 'general grammar of security' each sector - political, societal, military etc. has a dialect of its own.
} 
associated with a threat [and] generally held to be threatening' (Wæver 2003, 15).

The three facilitating conditions to a large extent correspond to three layers of securitisation laid out by Stritzel. ${ }^{5}$ The first layer is 'the performative force of articulated threat text' although for Stritzel it goes beyond the mere grammar of security 'to also include the symbolic language of visuals/images and sound' (Stritzel 2007: 370). The second layer is the 'embeddedness of text in existing discourses' out of which securitising moves evolve. The third layer of securitisation is, according to Stritzel, 'the positional power of actors who influence the process of defining meaning' (Stritzel 2007: 370). In some cases this power will be officially delegated, but in others it may less direct or formal (Stritzel 2007: 372).

Another important issue that has been raised in the securitisation literature is the role of the audience for a successful securitisation (Léonard and Kaunert 2010). Thierry Balzacq was among the first who stressed that the force of securitising moves doesn't hinge on linguistic features of threat text only but that it rests with the audience. Moreover, he pointed out to the difference between 'moral' support of the general audience for extraordinary measures and 'formal' support of the institutions to adopt extraordinary measures. These two don't have to be congruent and the more congruent they are, the more successful a securitising move is (Balzacq 2005: 184).

These ideas were further taken by Mark Salter who critiqued the very idea of securitisation as being either successful or unsuccessful and argued that it is instead always a matter of degree. Consequently, he made a useful distinction between various degrees of success of securitising moves: low success exists when an issue is discussed in a security mode; medium low success exists when there is acceptance/rejection of the security text; securitising move has medium high success when its proposed solutions and extraordinary measures are accepted; securitisation is highly successful when new emergency powers are accorded to the securitising agent (Salter 2008).

Taking these ideas on, in the rest of this article we analyse securitising moves made in the wake of the 2010 Belgrade Pride Parade, to which audiences that they were directed, how successful they were in convincing these audiences and why. In particular, we investigate the

\footnotetext{
${ }^{5}$ It is worth noting that Holger Stritzel has critiqued the model presented by Buzan, Wæver and De Wilde for its implicit tension between two centres of gravity: internal and external. The internal centre of gravity encompassed in the first facilitating condition is post-structuralist as it focuses on the grammar of security and the threat text itself. The external centre of gravity, contained in the second and third facilitating conditions, is according to Stritzel, social-constructivist as it focuses on the context in which a securitising move takes place (Stritzel 2007).
} 
grammar of speech acts made around the Pride Parade, their embededness into wider discourses and the positional power of securitising actors who made those speech acts to understand why they had such a limited success in convincing the government of Serbia to adopt extraordinary measures.

\section{Research Puzzle and Empirical Analysis}

In the wake of the Belgrade Pride Parade, scheduled for October 10, two opposed groups have tried to frame the event as a dramatic test for the survival of the Serbian polity. On the one side were liberal proponents of the Parade, such as LGBTIQ organisation and human rights NGOs, who called the government to prevent or even ban the extremist right wing groups portrayed as a threat to democracy. On the other side were conservative opponents of the Parade, among whom the most vocal were the Serbian Orthodox Church (SOC) and right wing organisations such as Dveri, Obraz and 1389. They requested from the Government banning of the parade, which in their view threatened national dignity and insulted public morals. ${ }^{6}$ Both liberal and conservative securitising actors requested that the Government of Serbia breaks the normal rules of the game: while the liberal in effect requested the suspension of freedom of speech for the opponents of the Parade, the conservative requested the suspension of freedom of public assembly for the LGBITQ people. ${ }^{7}$

Nevertheless, these mutually opposing securitising moves were only partially successful. Truth to be told, both camps managed to obtain the moral support of at least part of the general audience. Thanks to their securitising moves, the media discourse about the parade was highly emotional and deeply polarised. Moreover, these moves mobilized thousands of protesters to take to the streets. ${ }^{8}$ Still, neither of the moves obtained the formal support of the state for extraordinary measures that 'break the normal political rules of the game' (Buzan et al. 1998: 24). The Pride Parade was allowed to take place on 10 October and the freedom of assembly,

\footnotetext{
${ }^{6}$ Many other actors, including state representatives, also used security language when discussing the event. However, as they did not advocate for the adoption of extraordinary measures that break the normal rules of the game and for the expansion of security prerogatives that would not otherwise be seen as legitimate, these actors were not treated as securitising actors in this article.

${ }^{7}$ It should be noted that not all conservative opponents of the parade called for violence against LGBTIQ people or even for banning of the event. By the same token, not all liberals called for harsher security measures against the right wing extremists either. In this article, only the actors on both sides of the political spectrum who called for some sort of extraordinary action will be treated as (liberal of conservative) securitising actors.

${ }^{8}$ While there were around 1000 peaceful protesters at the parade, the counter demonstrations gathered around 6,000 people (B92 2010b).
} 
which is a constitutionally guaranteed right, was not suspended. The state authorities didn't heed to the requests made by other camp either, to use additional security prerogatives in order to prevent the right wing groups from taking to the streets. As Nielsen rightly notes, 'the police and the civilian intelligence agency arguably had plenty of advance warning and could have acted pre-emptively to stop the rioting' (Nielsen 2013a, 1042). But they didn't.

In fact, the degree of success of securitising moves in the wake of the 2010 Pride Parade was low (to use Salter's terms discussed earlier) as the issue was only discussed in a security mode, whereas extraordinary measures that were requested by securitising actors were not taken by public authorities nor new competences were accorded to the state (Salter 2008). As a result, the state was unable to prevent more than 6000 anti-Pride demonstrators to take to the streets and clash with police. The balance sheet of the protest was 140 injured and 207 arrested people and vandalised city centre including the HQ of major political parties (Miller 2010).

How can such an outcome be explained? Why did both securitising moves fail to convince the Serbian government to adopt extraordinary measures? Did the security speech acts fulfil all three facilitating conditions needed for successful securitisation related to the grammar, discursive context and positional power of the actors? To answer these questions, we first present a content analysis of the media coverage of the Pride Parade, and then triangulate it with a discourse analysis of securitised speech acts. The mixed method approach will allow us to combine quantitative and qualitative insights and thus provide a fuller account of why these opposing securitising moves had such a limited success.

\section{Content analysis of media coverage}

Critical security studies have traditionally been much more concerned with theory than with methodology (Salter and Mutlu 2013). As Baele and Sterck have recently pointed out, 'Methods are indeed the Achilles' heel of securitisation studies' (Baele and Sterck 2014, 3). In order to mend this gap, several scholars have called for a more rigorous methodology in securitisation research but also encouraged more innovative approaches such as the triangulation of qualitative and quantitative methods in securitisation studies. We heed to these calls by combining (quantitative) content with (qualitative) discourse analysis of the 2010 Pride Parade. In the content analysis presented bellow, we aim to quantitatively assess the presence of securitised speech acts in the media coverage of the 2010 Pride Parade. By providing quantitative insight 
securitisation process, content analysis helps us better understand the resonance of particular securitising moves and the degree of their success.

The content analysis covered 420 units published between 20 September and 31 October 2010 on the topic of the Pride Parade in six print and four broadcasting media. ${ }^{9}$ When the print media are concerned, the material covered in the research was published in two major broadsheets (Politika and Danas) and four tabloids (Blic, Večernje Novosti, Press and Pravda). The material from the broadcasting media was presented by the public television station $(R T S)$ and three major private TV stations (B92, Pink and Prva). The unit of analysis was the newspaper article or news story within a TV program. ${ }^{10}$

The first variable that we have looked at in the content analysis is 'polarisation'. Here we have coded the degree of polarising speech acts contained in the analysed media coverage. Polarising speech was coded whenever negative language was used to depict one of the conflict parties involved and/or appealed to hostile action. All reports containing polarised speech acts were then categorised into moderate speech (factual language), somewhat polarising speech (moderate criticism) and strongly polarising speech (demonising language and unbridgeable differences). Our basic assumption was that the high level of polarisation positively corresponds with both the intensity and the frequency of securitising moves.

The content analysis of polarisation has shown that the overall media discourse about the Pride Parade was highly polarised. Out of 420 analysed units only 28 or $6.6 \%$ had no speech acts about conflict parties at all, while 179 units (42.6\%) were highly polarized, 181 units (43.1\%) were somewhat polarized while only $32(7.6 \%)$ were expressed in a moderate speech. This means that only $6.6 \%$ of the media coverage certainly didn't contain any securitising moves, whereas a staggering $42.6 \%$ contained speech acts in which conflict parties demonised each other and were therefore partially or fully following the grammar of security.

The second variable 'treatment option' captures preferences for different approaches in dealing with the Pride Parade expressed by various voices present in media reports. In particular, we have focused on speech acts containing preferred or advocated solutions to the conflict. Each

\footnotetext{
${ }^{9}$ The period covered in the content analysis was extended until 31 October in order to capture not only the speech acts made before but also after the parade took place. This gives us a fuller insight into the media representation of the entire event.

10 The codebook consisted of 37 variables, 11 of which were used in this article which are 'voice 1' (V13), 'voice 2' (V14), 'voice 3' (V15), 'conflict party 1' (V24), 'conflict party 2' (V25), 'treatment option' (V27), 'evocation of the past' (V32), 'overall tone: emotions' (V34), 'overall tone: bias' (V35) and 'overall tone: polarisation' (V36). A group of two PhD student coders from the Faculty of Political Sciences/University of Belgrade were trained to code the sample. Inter-coder reliability (proportion agreement) was .93
} 
media report containing a treatment solution was then coded as expressing preference for one of the following categories of treatment: [a] evolution/gradual change - [b] revolution/radical, fast change; [a] compromise/negotiation/cooperation with other conflict party - [b] no compromise/no negotiation or cooperation; [a] peaceful - [b] violent; [a] toleration - [b] intolerance, repression or [a] institutional - [b] cultural.

Interestingly enough, in only $11.4 \%$ 'non-securitized' solutions such as evolution, compromise/negotiation, peaceful measures and toleration were preferred. In a staggering $82.9 \%$ of the analysed media reports 'securitised' solutions such as revolution/radical, fast change, no compromise, no negotiation or cooperation, violence or repression were advocated. Another important, finding was that liberal actors used securitised speech much more rarely than the conservative ones. They expressed preference for peaceful and ordinary measures in $85.7 \%$ of media reports where they had a voice while in only $14.3 \%$ of the cases they suggested extraordinary treatment solutions. Conservative and militant actors called for extraordinary measures in $42.9 \%$ and for regular treatment solution in $41.9 \%$ of cases, clearly suggesting a higher level of securitisation in their speech.

The third variable that we have looked at in the content analysis is 'emotions'. In this variable we coded all references to feelings and categorised all units into unemotional, somewhat emotional and inflammatory. ${ }^{11}$ Our starting point was that high emotionality in general facilitates securitisation process (Senn 2016). Consequently, we assumed that the level of emotionality in the media discourse about the Pride Parade corresponded positively with a persuasive force that securitising moves had on their target audiences. The results showed that in the media coverage of the Pride Parade, $16.2 \%$ of all the reports were inflammatory, $42.2 \%$ contained some emotional language, while the remaining $41.5 \%$ were made in a detached manner (Table 1 ). This means that majority of media coverage of the 2010 Pride Parade was emotional which facilitated securitisation moves.

[Table 1 near here]

\footnotetext{
${ }^{11}$ In this variable we coded only references to feelings that are explicit in the text. If a reference to normal feelings (e.g. 'I fear that...') was present in the text we coded the article as 'somewhat emotional'. In cases when attributes of strong feelings were present in the text (e.g. 'I was utterly terrified to hear..') were present, we coded the article as 'inflammatory'.
} 
The fourth variable that we have investigated is 'bias' or the extent to which media reporting on the 2010 Pride Parade was on the whole supportive of a particular camp in the conflict. All media reports were categorised as neutral (predominantly factual, don't contain biased messages), balanced (with biased messages, but covered equally), somewhat biased and biased. Our starting assumption was that the high level of bias in the reports also acted as a facilitator of all speech acts made in the report including securitising moves. In contrast, a neutral or balanced report, even if it contained securitised speech acts, would be in theory balanced by counterarguments thus diluting the performative force of its speech acts.

The results of the content analysis show that the media coverage was rather biased, with only $10 \%$ of the units written in a neutral fashion, $15 \%$ was balanced, while $42 \%$ of them was somewhat biased and $32.6 \%$ very biased (Table 1). We can assume that relatively high level of biased reports, caused most likely by the lack of consensus among elites about the Pride Parade, helped to further deepen societal polarisation and facilitate securitising moves made by both sides.

In order to assess the embeddedness of securitising moves in a wider discursive context we have focused in the content analysis on whether they evoked 'aspects historically associated with a threat [and] generally held to be threatening' (Wæver 2003, 15). To that end we have included in the analysis the fifth variable: 'evocation of the past'. To fully inspect this variable, we also analysed evocation of the past in relation to the other variables, such as voice and polarisation. Our analysis has shown that both camps very rarely evoked any direct historic precedent in order to make their warnings more credible. For example, only $17.3 \%$ of the highly polarized reports included any evocations of the past (Table 2). Out of that, $32.3 \%$ referred to the past violence of 2001, while other reports used other historic references either directly related to past attempts to organise pride parade (in 2009 example) or other events from history important for democratisation and violence.

It is noteworthy that, in the analysed sample at least, militant actors never used the evocation of the 2001 violence. This is understandable as although the evocation of past violence from 2001 could indeed make their present threat of violence more credible, it would only strengthen the case made by their opponents. For the same reason, the historic precedent from 2001 was in most of the analysed cases evoked by civil society actors (56\%), while other actors such as political authorities (12\%), religious groups (8\%) and international community (8\%) did it more 
rarely. This finding is expectable, as the reference to 2001 was an argument working clearly in favour of the liberal move, which construed the right wing violence as a threat to human rights and democracy.

[Table 2 near here]

Finally, we have used the content analysis to measure the overall accessibility to media of different camps in the debate and the way they were treated in the media. For that purpose we have analysed the variables: 'voice 1', 'voice 2' and 'voice 3'. In these variables we have coded the three most prominent actors (individuals or institutions) who were directly quoted in any unit and in the order of their appearance and importance. Furthermore, we included in the analysis variables 'conflict party 1' and 'conflict party 2' where we have coded the two main conflict parties covered in the article and attributes that were used to describe them. The starting assumption was that both accessibility of media to different actors and the media coverage of their activities will be good quantitative indicators of positional power wielded by the opposing camps in the context of the 2010 Pride Parade.

Our content analysis has shown that neither the right wing extremists nor LGBTIQ actors featured in the media coverage as the most important voices in the debate about the Pride Parade. In $32.8 \%$ of all media reports about the 2010 Pride Parade, the first voice was given to national political authorities, $28.4 \%$ to ordinary citizens and experts, $9.2 \%$ to political parties while in only $13.9 \%$ of cases it was given to LGBTIQ and human rights NGOs who most often used securitised speech acts. In a meagre $6 \%$ of units the first voice in a media report was given to militant and right wing actors. Conservative and liberal securitising actors were represented as the second voice (in cases when there was any) in an equally small proportion (7.4\%). This means that the biggest space in the media was given to the state officials who in 2010 didn't use the security speech acts in public. ${ }^{12}$

\footnotetext{
${ }^{12}$ It should be noted, however, that behind the scenes, the Serbian Police engaged in backstage securitisation. In contrast to their declaratory commitment to constitution and rule of law, in their communication with the organisers of the event, the police exaggerated the threats to the parade and thus tried to convince them to call it off. This will change in 2011, 2012 and 2013 when the state officials publically used securising moves to justify the ban of the parade (Ejdus and Božović 2016).
} 
Interestingly, our analysis of attributes attached to different actors sheds an additional light on their positional power. In fact, conservative securitising actors on the whole where framed in a rather negative light. In $74.2 \%$ of all the media reports, conservative actors (including the SOC) were given negative attributes, while they were attributed positively in only $22.4 \%$ units. This could suggest that an otherwise high social capital of the SOC to shape public debate about national identity was tainted in this particular context due to its real or perceived ideological affinity with more marginal extremist organizations such as Obraz. The low positional power of liberal securitising actors was also reflected in the way media represented them in the context of the Pride Parade. In the vast majority of analysed media reports $(81.5 \%)$, liberal actors - such as the LGBTIQ organisations and other human rights NGOs - were described with negative attributes, while they were described with positive attributes in only $11.1 \%$ of articles.

In sum, the content analysis has shown that the media coverage of the Pride Parade was highly polarised, very emotional, incredibly biased and heavily loaded with calls for extraordinary action. Moreover, the analysis has demonstrated that security speech acts very rarely evoked the past events, which certainly didn't strengthen the case for exceptional measures. Finally, the content analysis has lain bare that actors calling for exceptional politics had much less access to the Serbian media than those who advocated 'business as usual' approach to the Pride Parade. Hence, the content analysis has indicated that although there was a high frequency of securitised speech acts in the media coverage of the 2010 Pride Pride, they didn't evoke historic associations and the actors who decisively framed the meaning of the event were the moderate voices, not the securitising actors. In the next section we move to the qualitative analysis of particular speech acts and securitising actors in order to shed additional light on the origins of their low success.

\section{Discourse analysis}

In this section, we employ discourse analysis, traditionally used in securitisation research, to gain a qualitative insight into security narratives about the 2010 Pride Parade. This will help us assess whether the securitising moves conducted in the wake of the event followed the grammar of security or not. Moreover, discourse analysis will enable us identify basic discourses in which these securitising moves were embedded in, including the 'representations of identities with particular conceptual histories' (Hansen 2006, 71). Finally, we will identify who the main securitising actors were and assess their positional power to define the meaning of security. The 
sources used for discourse analysis included Serbia's press published in September and October 2010 covered in the content analysis but also liberal Internet portals, websites of the far-right groups, graffiti and social media.

Our analysis shows that conservative securitising moves closely followed the grammar of security, particularly its dialect of societal security that is about large-scale collective identities (Buzan et al. 1998: 22). These moves portrayed LGBTIQ community and its public gathering as a threat to traditional patriarchal values of the Serbian society. Moreover, they warned that the Pride Parade represented a direct threat to traditional values of the Serbian nation. For example, in an interview published in one of the most widely circulated tabloid Kurir Mladen Obradović, the leader of a far-right organisation Obraz (Ser. Dignity) said: 'We warned them about the just anger of the Serbian people and we emphasized Serbian decisiveness not to back down in the fight against the shameful onslaught on the morals and health of the Serbian nation' (Kurir 2010a). Similar language was used by other right wing activists whose threatening messages were under the media spotlight for weeks before the parade. The labels they used to depict LGBTIQ and the Pride Parade, and the media casually broadcasted it, were 'poison', 'stench', 'parade of shame', 'Sodom and Gomorrah', 'paedophiles', 'clowns', 'exhibitionists', 'sick people', 'faggots, 'plague', 'pest' etc.

In order to fend off this threat, conservative actors requested that the public authorities suspend a constitutionally guaranteed freedom of assembly and ban the event. Thus, for instance, organisation Dveri (Ser. The Gates) officially requested that the Ministry of Internal Affairs of the Republic of Serbia 'ban the organization of the public gathering Pride Parade 2010 scheduled for 10 October 2010 in order to protect public health and morals' (Kurir 2010b). Opponents of the Parade especially targeted the security sector, without whose protection the event couldn't be organised in a safe manner. Thus, for instance, organisation Naši attended a meeting of the Serbian Police Union held on 5 October and distributed flyers with the following content:

Show the citizens of Serbia that you are not 'dogs', as some people call you, dogs who will take any order from the regime, but policemen who serve their own people. The orders, which are against the people, shall not be implemented. Don't go out to the streets on 10 October and the faggot parade scheduled for that day will be peacefully cancelled (B92 2010a).

Within conservative securitising moves one should distinguish between narratives that openly advocated violence and those that didn't. For example, organizations such as Obraz or 1389 openly threatened LGBTIQ people with violence. Threats were extensively made not only 
through the traditional media but also in graffiti spray-painted all over the city such as 'We are waiting for you' and 'Faggots, get out of Serbia', but also through chants and placards at sports events and in the social media. On Facebook alone there were at least 15 different anti-Pride Parade groups with names such as 'Blood will flow in Serbia, but the Parade will not take place' and '10/10/10 Storming of the Gay Parade' while the right wing groups also extensively used Youtube to share their hate speech (Youtube 2010).

In contrast to this, most conservative intellectuals and politicians as well as representatives of the SOC, shared the view that the Pride Parade is a threat to morality and national identity but stopped short of openly advocating violence against LGBTIQ people. The SOC for example, although traditionally vocal in its exclusion of LGBTIQ people from the imaginary community of 'true members of a nation', used somewhat less threatening but equally condemning discourse (Pavasović-Trošt and Slootmaeckers 2015). For example, one of the highest officials in the SOC, the Metropolitan Bishop of Montenegro Amfilohije Radović in an interview given three days before the Parade, called homosexuality: 'a deadly sin' and 'sodomy' (Pečat, 2010). Conservative politicians joined the fray by depicting the Parade as an onslaught on the health of the Serbian nation. Dragan Marković Palma, an MP of the United Serbia party, for example, called homosexuality 'a sickness' on a regular bases (Bojić 2010). Finally, some conservative intellectuals, while not advocating violence themselves, still justified the homophobic calls for violence as a legitimate anger of 'disenfranchised and unemployed' youth protesting against the 'vassal state', 'domestic European transvestites' and its 'Euro-Atlantic masters' (PavasovićTrost and Kovačević 2013, 1069).

Liberal securitising moves also followed the grammar of security but their dialect belonged to the political sector which is about the 'organizational stability of social order' (Buzan, Wæver, and De Wilde 1998, 141). They portrayed the nationalist groups such as Obraz, 1389 and Naši, as a threat to human rights, democracy, rule of law and public safety. Some of the labels strategically used to demonise and depict anti-Parade protesters as a threat were 'extremists', 'hooligans', ‘vandals', ‘fascist scum', ‘criminals', 'neo-Nazis', 'terrorists', 'wild mob', 'ultranationalists', 'racists', 'fanatics', 'bandits', 'baboons', 'homophobes', 'the Serbian Taliban', 'thugs', ‘private armies', 'Milosevic's hordes', 'madmen' and 'organized criminals'.

In addition to the regular measures expected to be taken in order to protect any public gathering, liberal securitising moves proposed preventive arrests of right wing leaders and banning of their organizations, including the soccer fan groups and even conservative 
organizations that did not advocate violence such as Dveri. Thus, for example, the Gay-Lesbian Info Centre issued a statement on 10 September requesting preventive arrest of the leader of militant group Obraz and explained their request as follows: 'So far the State and its organs have been shamefully lenient towards the perpetrators of violence [...] the Gay Lesbian Centre demands that the State respect its laws and start doing its job, and that is the fight against violence' (RTV 2010).

Both securitising moves were firmly embedded in the wider discursive struggles between a traditionalist basic discourse usually referred to as 'the first Serbia' and a modernist basic discourse referred to as 'the second Serbia'. ${ }^{13}$ Whereas the former basic discourse is conservative, nationalist, religious and Eurosceptic the latter basic discourse is liberal, antinationalist, secular and Europhile. These two basic discourses define the key ideological divide in Serbia and construe two different conceptions of national identity and political community. The opposition to the Pride Parade drew heavily from the symbolic reservoir of the traditionalist basic discourse and its values of patriarchal order, national pride, strong family and healthy nation under the constant onslaught of foreign enemies and their domestic collaborators. The strategy of the opponents of the parade, as Nielsen posits, 'was to identify the opposition to the parade as a "patriotic act" and hence as linked to support for the Serbian stance on Kosovo, opposition to NATO and the EU, etc.' (Nielsen 2013a, 1042).

The performative force of conservative securitising moves was stemming from their embeddedness in the wider identity narratives associated to the First Serbia. As Isidora Stakić has demonstrated, framing of the LGBTIQ people as the ultimate Other 'associated with immorality, crime, destruction of family, godlessness, evil, totalitarianism, shame, sin, and Western imperialism' served to (re) produce certain idea of the national Self in contrast to this chain of signifiers (Stakić 2015, 197). In other words, conservative securitising moves were based on a representation of morally right, national, popular, defensive, honest, destitute and pious Self pitted against morally wrong, cosmopolitan, elite, offensive, corrupt, wealthy and atheist Other. This is how, for example, the leader of Obraz depicted progressive actors in Serbia in an interview from 19 September 2010: 'They try to present every legitimate defence of the Serbian national interests as violence. When they talk about violence, they misrepresent the Serbian struggle for freedom. They call our defence - violence' (Zarković 2010). Then he explains why these organizations should be denied their constitutionally guaranteed freedom of

\footnotetext{
${ }^{13}$ Some authors translate this term (ser. "Druga Srbija") as 'the other Serbia' (Omaljev 2016).
} 
assembly:

By the way, in the past few years the representatives of these organizations have on multiple occasions swooped down, in the most vulgar and brassy way, on the Serbian Orthodox Church [...]. Nobody can convince me that people who are proud of these despicable acts are allowed to go into the streets and express their attitudes. How could this possibly benefit the Serbian society? (Zarković 2010)

On the other side, the performative force of liberal securitising moves was stemming from their strong embeddedness within the modernist basic discourse with its references to democratization, tolerance, emancipation and European values, all allegedly suppressed by the resilient forces of virulent nationalism. Liberal moves evoked an identity construct associated with the modernist basic discourse, of a vulnerable, liberal, enlightened, democratic, cosmopolitan, and European Self under the continuous onslaught of an aggressive, illiberal, irrational, anti-democratic, nationalist and even Orientalized Other. For instance, several days before the parade, one of the most prominent Human Rights activists in Serbia Goran Miletić called the enemies of the parade 'imps trying to prevent the citizens of Serbia (and Europe) to enjoy their constitutionally guaranteed freedom of peaceful association' (Miletić 2010). To emphasize that the struggle for LGBTIQ rights is part of a wider struggle for emancipation, one of the organizers of the Pride Parade, Boban Stojanović, said: 'Today we say that we are not only LGBT. We are also Roma men and women. We are every woman and every child and everyone who is repressed in this society' (Teodorović 2010).

Securitising actors on both sides had a variable positional power or 'the ability to influence a process of meaning construction' (Stritzel 2007, 373). The main conservative securitising actors were the right wing organizations such as Obraz and Dveri, 1389 and Naši (ser. Ours), but also the SOC, conservative political parties and right wing intellectuals. The key liberal securitising actors were the human rights organizations, LGBTIQ activists and liberal intelligentsia. Their moves were broadcasted by liberal leaning media outlets such as B92 and Blic and amplified through their alliance with liberal political forces on the inside and with the EU (and its member states) on the outside.

Generally speaking, within the conservative camp, the SOC held the strongest positional power to speak about matters pertaining to national identity and societal security. This stemmed from a widely shared perception of the SOC as the protector of the national identity and spirituality of the Serbian nation. Approximately $85 \%$ of Serbian citizens were (and still are) 
adherents of the SOC. Of all the public institutions, the SOC traditionally enjoys, together with the Armed Forces, the highest approval rates (Ejdus 2012, 233). Other conservative securitising actors held much weaker positional power than the Church. While Obraz was a fringe extremist organization, mobilizing mostly football hooligans and extreme nationalists from the margins of society, Dveri was in 2010 an organization with little credibility in the wider public. ${ }^{14}$

In the liberal camp, the strongest positional power to convince the state authorities to adopt extraordinary measures was held by the EU. However, neither the EU nor its member states directly supported the banning of militant organizations or preventive arrests of their leaders. Their only request from the public authorities was to adopt regular police measures necessary to secure the freedom of peaceful assembly. Other actors within this camp, such as LGBTIQ organizations or liberal intellectuals who issued more vocal requests for extraordinary measures against the militants, had very little if any positional power to convince the state authorities. After years of demonization as 'traitors' and 'foreign agents' many of those actors actually enjoyed little public support. The most important aspect of their positional power that they often used as leverage over the government's policies was their privileged position as the 'darlings' of the (western) international community.

The qualitative analysis above testifies that both securitising moves closely followed the grammar of security. Both liberal proponents and conservative opponents of the parade used speech acts that clearly designated the other as the threat to a defined referent object and requested from the authorities to take extraordinary measures which otherwise wouldn't be seen as legitimate. Moreover, the analysis has shown that both moves were firmly embedded in wider basic discourses about the Serbian polity and their identity constructions. While the conservative securitisation was resonating the basic discourse of 'the first Serbia', the liberal securitisation was embedded in the basic discourse of 'the second Serbia'. Nevertheless, the analysis has also demonstrated that these security speech acts were enunciated by actors with rather limited positional power. On both side of the divide, the most vocal actors who securitised the other side had a negligible power to define meaning while actors with a stronger positional power such as the state authorities and political parties, framed the Parade in a less dramatic tone.

In sum, security speech acts conducted in the wake of the 2010 Pride Parade followed the grammar and were strongly embedded in basic political discourses. However, these speech acts

\footnotetext{
${ }^{14}$ Dveri transformed into a political party in February 2011 and gained seats in the National Assembly for the first time after general elections held in 2016.
} 
had limited success in convincing the Serbian authorities to adopt extraordinary measure because they were not embedded into wider security discourses and were not made by actors with strong positional power.

\section{Conclusion}

In this article we applied securitisation theory to understand why a series of securitising moves made in the wake of the Belgrade 2010 Pride Parade had limited degree of success. In particular, by combining content and discourse analysis we analysed the performative power of threat text, the embeddedness of the threat text into wider discourses and the positional power of securitising actors to define the meaning of the parade.

We concluded that the security speech acts on both sides fully fulfilled only the first facilitating condition related to the grammar of security. Both quantitative and qualitative analyses have clearly shown that securitising moves closely followed the grammar of security. On the one side, conservative securitising actors framed the issue of the Belgrade Pride Parade as a societal threat to the moral order and national identity that needed to be urgently dealt with through extraordinary treatment such as suspension of constitutionally guaranteed freedom of assembly and banning the event. On the other side, liberal securitising actors framed the issue of violent extremism as a political threat to the constitutional order, rule of law and human rights that needed to be urgently dealt with through extraordinary treatment such as banning the right wing organizations and preventive arrests of their leaders. In addition to this, the content analysis has shown that these speech acts were not marginal incidents but massive phenomenon whose ubiquitous presence raised the overall level of polarisation, emotionality and bias in the media coverage. It has also revealed that conservative actors used much more frequently securitized speech acts in the media than liberals, which certainly contributed to the high level of violent mobilization on the day of the parade.

However, our analysis has shown that securitising moves have only partially fulfilled the second facilitating condition related to the context while they fell short of the third facilitating condition related to the positional power of the actors. The content analysis revealed that there was little use of historic precedents, which weakened the embeddedness of the threat text into the wider security context. On the other hand, discourse analysis has shown that the threat text was indeed embedded in the basic political discourses which increased its resonance. Finally, and probably most importantly for understanding the limited success of securitising moves, our 
analysis has revealed that the positional power of both conservative and liberal securitising actors was marginal, as opposed to other participants in the debate who didn't use securitising discourse to frame the Pride Parade. The actors who used security speech acts has little access to the media where they were usually depicted in a negative light.

Our analysis demonstrates the analytical purchase of triangulating content and discourse analyses in securitisation research. The content analysis has allowed us to measure the prevalence of securitised speech acts in the media coverage of the event, the overall accessibility of media for securitising actors and the frequency of historical associations made to past experiences of insecurity. Discourse analysis has helped us understand the meaning of particular securitisation moves and their links to basic discourses and representations of collective identity. Combined, the content and discourse analyses have helped us to provide a fuller answer to the research question of this article and argue more comprehensively that security speech acts around the Pride Parade had low success, especially in obtaining the formal support of the state to adopt extraordinary measures, not due to the features of the threat text but to the features of the context, in particular due to the low social capital of securitisers. Their intensive campaign has managed to ignite the public sphere, polarise society and mobilize people to take to the streets. However, what they failed to achieve was to obtain the formal support of policy makers who decided not to break the normal rules of the game. This will change in the following years when the state authorities adopted the security discourse, mostly informed by the vivid memories of 2010 violence.

However, our argument comes with one important caveat. Not in the least is our assertion that the weak positional power was the only cause of the puzzling outcome of 2010 Belgrade Pride Parade. In order to assess the weight of securitisation as a causal mechanism, a different type of methodology would be warranted (Guzzini 2011). It should be noted that an internationally supported Pride Parade was highly unpopular in Serbia, and a repressive crackdown on its opponents could seriously hurt the approval rates of the Serbian Government which was at the time led by centre-left Democratic Party. Hence, the government wanted to simultaneously respect the rule of law, satisfy the EU and cater to widely spread homophobic sentiments which the conservative opposition was trying to capitalise upon. A part of the explanation could also lie in under-researched connections between right wing organisations that took to the streets, political parties and the security sector. These and other approaches could be used in future studies to capture aspects of the event uncovered in our analysis. 
Although our analysis has focused on 2010, it is noteworthy that in the following years, the state transformed into the most powerful securitising actor. Security narratives embraced by the state representatives until 2013 combined liberal concerns about the extreme right wing with conservative bias against LGBTIQ. Consequently, the Pride Parade was banned three years in a row while the state has gradually cracked down on the extremist organisations such as Obraz and 1389. In January 2014, Serbia opened accession negotiations and the leverage of the EU over domestic politics increased even further. In the meantime, many of the organizations although not all - that opposed the parade in 2010 were banned, and the Serbian Police had indeed implemented a number of preventive security measures. As a result, on 28 September 2014 Belgrade had the first peaceful Pride Parade in its history, albeit heavily enforced by the Serbian Police and this has been repeated in 2015. Future studies could investigate the relevance of (de) securitisation moves, and especially the significance of the changing political and media landscape for this outstanding policy transformation that took place between 2010 and 2014 .

\section{References:}

Aradau, Claudia. 2004. Security and the democratic dcene: desecuritization and emancipation. Journal of International Relations and Development 7, no. 4: 388-413.

Ayoub, Phillip, With arms wide shut: Threat perception, norm reception, and mobilized resistance to LGBT Rights, Journal of Human Rights, 13, No. 4: 337-362.

B92. 2010a. Zašto država toleriše klerofašizam? B92, October 9. http://www.b92.net/info/vesti/index.php?yyyy=2010\&mm=10\&dd=09\&nav_id=46420 4 (Accessed March 12 2015).

B92. 2010b. Demoliranje Beograda još jednom. B92. October 10. http://www.b92.net/info/vesti/index.php?dd=10\&mm=10\&nav_category=16\&nav_id=4 64314\&yyyy=2010 (Accessed July 29 2016).

Baele, Stéphane J, and Olivier C Sterck. 2015. Diagnosing the securitisation of immigration at the EU level: A new method for stronger empirical claims. Political Studies 63 no.5: 1120-1139.

Balzacq, T. 2005. The three faces of securitization: political agency, audience and context. European Journal of International Relations 11, no. 2:171-201.

Balzacq, Thierry. 2010. Securitization theory: How security problems emerge and dissolve. London: Routledge.

Balzacq, Thierry. 2014. The Significance of tiangulation to critical security studies. Critical Studies on Security 2, no. $3: 377-381$.

Bilgin, P. 2011. The politics of studying securitization? The Copenhagen School in Turkey. Security Dialogue 42, no. 4-5: 399-412.

Bilić, Bojan. 2016. Whose pride? The 'LGBT community' and the organization of Pride Parades in Serbia. In The EU enlargement and gay politics: The impact of Eastern enlargement on rights, activism and prejudice. ed. Koen Slootmaeckers, Helen Touquet and Peter Vermeersch, London: Palgrave Macmillan. 
Blic 2010. Crkva dala vetar u leđa protivnicima gej parade [online]. Blic. October 9. http://www.blic.rs/Vesti/Tema-Dana/211033/Crkva-dala-vetar--u-ledja--protivnicimagej--parade Accessed February 92015.

Bojić, Biljana. 2010. Homoseksualci ne odustaju: Gej parada 10. oktobra. Press, September 7. http://www.pressonline.rs/info/politika/132312/homoseksualci-ne-odustaju-gej-parada10-oktobra.html (Accessed March 12 2015)

Buzan, Barry, and Ole Wæver. 2009. Macrosecuritisation and security constellations: reconsidering scale in Securitisation Theory. Review of international studies 35, no. 2: 253-276.

Buzan, Barry, and Ole Waever. 2003. Regions and powers: the structure of international security. Cambridge: Cambridge University Press.

Buzan, Barry, Ole Wæver, and Jaap De Wilde. 1998. Security: a new framework for analysis. Boulder CO: Lynne Rienner Publishers.

Croft, Stuart. 2012. Constructing ontological insecurity: The insecuritization of Britain's Muslims. Contemporary Security Policy 33, no.2: 219-235.

Ejdus, Filip. 2012. State building and images of the democratic soldier in Serbia. In Democratic civil-military relations: soldiering in 21st century Europe, ed. Sabine Mannitz, 226-248. London: Routledge.

Ejdus, Filip and Mina Božović. 2016. Europeanisation and indirect resistance: Serbian police and Pride Parades. The International Journal of Human Rights. Advanced online publication appeared on 31 March.

Floyd, R. 2011. Can Securitization Theory be used in normative analysis? Towards a just Securitization Theory. Security Dialogue 42, no. 4-5: 427-439.

Gould, John A, and Edward Moe. 2015. Nationalism and the struggle for LGBTQ R rights in Serbia, 1991-2014. Problems of Post-Communism 62, no. 5: 273-286.

Guzzini, S. 2011. Securitization as a causal mechanism. Security Dialogue 42, no. 4-5 :329341.

Hansen, L. 2011. The politics of securitization and the Muhammad cartoon crisis: A poststructuralist perspective. Security Dialogue 42, no. 4-5:357-369.

Hansen, Lene. 2006. Security as practice: discourse analysis and the Bosnian war. London: Routledge.

Kurir. 2010a. Srbi a nacisti. Kurir, July 26. http://www.kurir.rs/srbi-a-nacisti-clanak-42326 Accessed November 42015.

Kurir. 2010b. Srpske Dveri: Branimo porodicu, otkažite "paradu". October 9. http://www.kurir.rs/srpske-dveri-branimo-porodicu-otkazite-paradu-clanak-52590 Accessed November 52015.

Léonard, Sarah, and Christian Kaunert. 2010. Reconceptualizing the audience in securitization theory. In Securitization Theory: How security problems emerge and dissolve, ed. Thierry Balzacq, 57-76.

Matić, Milan. 2000. O srpskom političkom obrascu. Beograd: Službeni List.

McDonald, Matt. 2008. Securitization and the construction of security. European journal of international relations 14 , no. 4: 563-587.

Mihajlović, Branka. 2010. Ekstremisti pod zaštitom. Slobodna Evropa, September 22. http://www.slobodnaevropa.org/content/srbija_ekstremisti_desnicari_napadi_novinari_ kazne/2165292.html Accessed March 122010.

Miller, Rob. 2010. Gay pride shows Serbia's progress", Guardian, October 11. http://www.theguardian.com/commentisfree/2010/oct/11/gay-pride-serbia-progress Accessed 17 May 2016.

Mikuš, Marek. 2011. "State Pride" Politics of LGBT Rights and Democratisation in "European Serbia." East European Politics \& Societies 25, no. 4: 834-851. 
Miletić, Goran. 2010. Parada (još 7): Palma i drugi vragolani. B92 Blog, October 3. http://blog.b92.rs/text/16181/Parada-jos-7\%3A-Palma-i-drugi-vragolani/ Accessed March 122015.

Nielsen, Christian Axboe. 2013. Stronger than the state? Football hooliganism, Political Extremism and the gay Pride Parades in Serbia. Sport in Society 16, no. 8: 1038-1053.

Omaljev-Russel, Ana. 2016. Divided we stand: Discourses on identity in 'First' and 'Other' Serbia, Stutgart: Ibidem Verlag.

Pavasović-Trošt, Tamara, and Nikola Kovačević. 2013. Football, hooliganism and nationalism: the reaction to Serbia's gay parade in reader commentary online. Sport in Society 16, no. 8: 1054-1076.

Pavasović Trošt, Tamara, and Koen Slootmaeckers. 2015. Religion, Homosexuality and Nationalism in the Western Balkans: The Role of Religious Institutions in Defining the Nation. Leiden: Brill.

Pečat. 2010. Mitropolit Amfilohije: kolo smrti na ulicama Beograda, Pečat, October 7. http://www.pecat.co.rs/2010/10/mitropolit-amfilohije-kolo-smrti-na-ulicama-beograda/ Accessed May 172016.

Pram Gad, Ulrich, and Karen Lund Petersen. 2011. Concepts of politics in securitization studies. Security Dialogue 42, no. 4-5:315-328.

Roe, Paul. 2008. Actor, audience(s) and emergency measures: securitization and the UK's decision to invade Iraq Security Dialogue, 39, no. 6: 615-635.

Roe, Paul. 2012. Is Securitization a "negative" concept? Revisiting the normative debate over normal versus extraordinary politics. Security Dialogue 43, no. 3: 249-266.

RTV. 2010. Gej-lezbejski centar traži hapšenje predsednika pokreta Obraz, B92, September 10. http://www.rtv.rs/sr_ci/drustvo/gej-lezbejski-centar-trazi-hapsenje-predsednikapokreta-obraz_210853.html Accessed March 122016.

Salter, Mark B. 2008. Securitization and desecuritization: a dramaturgical analysis of the Canadian air transport security authority. Journal of International Relations and Development 11, no. 4:321-349.

Salter, Mark B, and Can E Mutlu. 2013. Research methods in critical security studies: An introduction. London: Routledge.

Senn, Martin. 2016. The art of constructing (in)security: probing rhetorical strategies of securitisation. Journal of International Relations and Development. Advanced online publication appeared on 18 March.

Stakić, Isidora. 2015. Securitization of LGBTIQ minority in Serbian far-right discourses: A post-structuralist perspective. Intersections. East European Journal of Society and Politics 1, no. 1: 183-206.

Stritzel, Holger. 2007. Towards a theory of securitization: Copenhagen and beyond. European Journal of International Relations 13, no. 3: 357-383.

Teodorović, Miloš. 2010. Parada uspela iz trećeg pokušaja. Slobodna Evropa, October 10. http://www.slobodnaevropa.org/content/parada_ponosa_uspela_iz_treceg_pokusaja/218 6361.html Accessed March 122015.

Vultee, Fred. 2010. Securitization as a media frame. In Understanding Securitisation Theory: How security problems emerge and dissolve, ed, Thierry Balzacq, 77-93. London: Routledge.

Vuori, Juha. 2011. Religion bites: Falungong, securitization/desecuritization in the People's Republic of China. in Understanding Securitisation Theory: How security problems emerge and dissolve, ed, Thierry Balzacq, 186-212. London: Routledge.

Vuori, Juha A. 2008. Illocutionary logic and strands of securitization: Applying the theory of securitization to the study of non-democratic political orders. European Journal of International Relations 14, no.1: 65-99. 
Wæver, Ole. 1989. Security, the speech act: Analyzing the politics of a word. Working Paper 19, Copenhagen: Centre for Peace and Conflict Research.

Wæver, Ole. 1995. Securitization and desecuritization. In On Security, ed. Ronnie Lipshutz, 46-86. New York: Columbia University Press.

Wæver, Ole. 2003. Securitisation: Taking Stock of a Research Programme in Security Studies." Unpublished draft.

Wilkinson, Claire. 2007. The Copenhagen School on tour in Kyrgyzstan: Is Securitization Theory useable outside Europe?" Security Dialogue 38, no. 1: 5-25.

Williams, Michael C. 2003. Words, images, enemies: Securitization and international politics. International Studies Quarterly 47, no. 4: 511-531.

Youtube. 2010. Gej parada ne sme proći, čuvajmo obraz https://http://www.youtube.com/watch?v=MMwAjVgfxNM. Accessed March 122015.

Zarković, Miodrag. 2010. Mladen Obradović: optužuju nas da smo nasilni oni koji su nasiljem prigrabili vlas. Pečat, September 17. http://www.pecat.co.rs/2010/09/mladenobradovic-optuzuju-nas-da-smo-nasilni-oni-koji-su-nasiljem-prigrabili-vlast// Accessed March 122015.

Appendix:

Table 1

Percentages for each category of variables overall tone: emotions $(n=419)$ and overall tone: bias $(n=420)$

\begin{tabular}{lclc}
\hline Emotions & $\%$ & Bias & $\%$ \\
\hline Detached/neutral language & 41.5 & Neutral & 10.0 \\
Some emotional language & 42.2 & Balanced & 15.0 \\
Very emotional, inflammatory & 16.2 & Somewhat biased & 42.4 \\
language & & & 32.6 \\
& & Very biased & \\
\hline
\end{tabular}




\section{Table 2}

Percentages for each category of variable evocation of the past $(n=66)$

\begin{tabular}{lclc}
\hline Categories & $\%$ & Categories & $\%$ \\
\hline Attempts to organize pride parade & 37.9 & Serbia: Communism & 4.5 \\
Anti-regime actions & 19.7 & (Civil) war & 3.0 \\
Serbia: Milošević regime & 15.2 & National identity and traditions & 1.5 \\
The 2004 violence against Kosovo & 7.6 & Involvement in/support of regime & 1.5 \\
Serbs & & & \\
Serbia & 7.5 & The Kosovo conflict & 1.5 \\
& & & \\
\hline
\end{tabular}

